\title{
Matrix metalloproteinases (MMP's) in the rat scoliotic intervertebral disc
}

\author{
Theodoros B Grivas*, E Vasiliadis, L Khaldi, A Kaspiris, D Kletsas \\ From 7th International Conference on Conservative Management of Spinal Deformities \\ Montreal, Canada. 20-22 May 2010
}

\section{Introduction - aim}

The response of the intervertebral disc to asymmetric forces may accelerate degeneration through changes in the matrix. At a macroscopic level the disc sustains structural changes which may play a role in the progression of a scoliotic curve. At a molecular level, disc degeneration is the outcome of the action of matrix metalloproteases (MMPs), members of a family of enzymes responsible for the degradation of extracellular matrix components. In the present experimental study we measured in vivo the expression of MMP's in a rat scoliotic intervertebral disc and studied the impact of the degree of the deformity on their production.

\section{Material - methods}

Asymmetric forces were applied in the intervertebral disc between the 9th and 10th vertebrae at the base of a rat tail with the use of a mini Ilizarov external fixator, under anesthesia. Animals were categorized into three groups according to the degree of the deformity. In group I, the deformity which was applied on the intervertebral disc was $10^{\mathrm{C}}$, in group II $30^{\mathrm{C}}$ and in group III $50^{\mathrm{C}}$. All the animals used were female Wistar rats before adulthood, in order to take into account the impact of growth for the study of intervertebral disc changes. The intact intervertebral discs outside of the fixator were used as controls. After rats' sacrifice on 35th day, the tails were prepared and analysed using an immunohistochemical protocol for chromogenic detection and location of MMP's 1 , and 12 in tissue sections of the intervertebral discs.

\section{Results}

An increase of the concentration of the MMP's was found in all groups compared with the controls. The

Department of Trauma and Orthopaedics, "Tzanio" General Hospital of Piraeus, Greece

Full list of author information is available at the end of the article quantity of the MMP's increased as the degree of the deformity progressed. MMP's were detected mainly in fibrocartilage cells of the degenerative part of which were formed as result of the compression forces. A differentiation of a large number of disc cells into chondrocytes was observed at the transitional zone of the intervertebral disc adjacent to the vertebral end plates.

\section{Conclusion}

The application of asymmetric forces on the intervertebral discs of a rat tail results in an increase of MMP's expression in the disc cells. The amount of MMP's produced is proportional to the degree of the deformity and has an asymmetrical pattern of distribution into the intervertebral disc.

Published: 10 September 2010

doi:10.1186/1748-7161-5-S1-018

Cite this article as: Grivas et al:: Matrix metalloproteinases (MMP's) in the rat scoliotic intervertebral disc. Scoliosis 2010 5(Suppl 1):018.

Submit your next manuscript to BioMed Central and take full advantage of:

- Convenient online submission

- Thorough peer review

- No space constraints or color figure charges

- Immediate publication on acceptance

- Inclusion in PubMed, CAS, Scopus and Google Scholar

- Research which is freely available for redistribution

Submit your manuscript at www.biomedcentral.com/submit

\section{Biomed Central}

